\title{
CHEMOTHERAPY OF LEPROSY WITH DIETHYL-DITHIOL-ISOPHTHALATE 'ETISUL'
}

\author{
by TADASHi HiRako,
}

National Leprosarium, Tama Zenshoen.

The treatment of leprosy has gradually improved since numerous anti-leprosy drugs have been introduced not only sulphone compounds such as D.D.S. but also other types of preparations, thiourea derivatives, and antibiotics. Until ETISUL was recently reported to be effective for tuberculosis and also leprosy, there were no effective drugs for external use, in spite of the fact that one of the main lesions of leprosy is found in the skin. The results of its use obtained in a clinical trial for leprosy in Japan, has also confirmed ETISUL to be effective. Following are these findings, along with my evaluation.

\section{Method of application}

As a rule, the preparation was used alone, and it was rubbed into the skin, five days a week, in 5 to $10 \mathrm{gm}$. doses each time. A bath was taken several hours after the inunction to wash it off.

\section{Cases treated}

A total of 21 cases were treated with ETISUL, 15 lepromatous leprosy and six non-lepromatous leprosy.

TABLE 1

\begin{tabular}{|c|c|c|}
\hline & $\begin{array}{c}\text { Lepromatous } \\
\text { leprosy }\end{array}$ & $\begin{array}{c}\text { Non-lepromatous } \\
\text { leprosy }\end{array}$ \\
\hline 1. Fresh untreated cases & 8 & 6 \\
\hline 2. Reactional cases: & & \\
\hline (1) Pseudo-exacerbation & 3 & 0 \\
\hline (2) E.N.L. & 1 & 0 \\
\hline (3) Others & 2 & 0 \\
\hline 3. Relapsing cases & 1 & 0 \\
\hline Total & 15 & 6 \\
\hline
\end{tabular}

\section{Results of treatment}

In all cases, it was noted that there was a reduction of infiltration, redness and swelling, as well as destruction of bacilli.

In the cases of epithelioid cell reactional stages, such as Pseudoexacerbation or Acute Infiltration in lepromatous leprosy and tuberculoid change in non-lepromatous leprosy, the infiltration of the skin eruptions promptly disappeared, and the general conditions were greatly improved.

In the cases of lepromatous leprosy, with the continuation of treatment, macroscopic reduction in size and thickness of leproma 
as well as disappearance or improvement of infiltration were also observed clearly.

However, the efficacy of the preparation ceased after about six months in Case 1, about three months in Case 2 and about two months in Case 8. As the treatment continued infiltration, redness and swelling gradually increased again.

Concerning the occurrence of E.N.L., it was impossible to see the direct influence of this preparation, because the drug was used for a short period, and only a few cases were treated. Neither epithelioid cell reaction, nor neuralgia were observed when ETISUL was used.

Examination of the skin smears showed no remarkable decrease of the bacillary index, but all bacilli were fragmented morphologically.

After the application of ETISUL, lesions of nasal mucosa were greatly improved as were skin lesions.

In ocular lesions, however, it showed little efficacy.

\section{Side-effects}

No disturbance was observed in liver, kidney, haematopoietic organs or other organs.

However, dermatitis was frequently seen in many patients. There were two kinds of dermatitis. One was seen among the patients who received ETISUL for a few days (Case 12, 13, 14, 15, 17, 18, 19, 21). The other was frequently noted in patients who tolerated ETISUL one or two months but then developed dermatitis after that. The dermatitis gradually increased in severity in the latter. It began with red miliary papules, and then developed an appearance of eczematous changes. In those cases, the dermatitis disappeared soon when inunction was ceased, or could be cured by the usual ointment application on the affected area. However, the same kind of eruption recurred gradually when ETISUL was used again.

\section{Evaluation}

From the results obtained by the sole use of ETISUL in the treatment of leprosy, although only a small number of cases was treated, it could be said that ETISUl has a therapeutic effect on leprosy. In the treated cases, clinico-morphological improvement such as reduction and absorption of infiltration occurred. There was lessening of swelling in the lesions; bacteriologically, a fragmentation of bacilli was observed.

In the cases of tuberculoid reactions, however, the eruption often disappeared spontaneously. Therefore, it is difficult to evaluate the efficacy of this drug to the reaction. But ETISUL was interpreted as effective in my experience, because disappearance of the eruption seemed to be accelerated when ETISUL was employed.

In the cases of epithelioid cell reactions in lepromatous leprosy (Case 3 and 4), although the bacillary index conspicuously fell, it 
Case 1

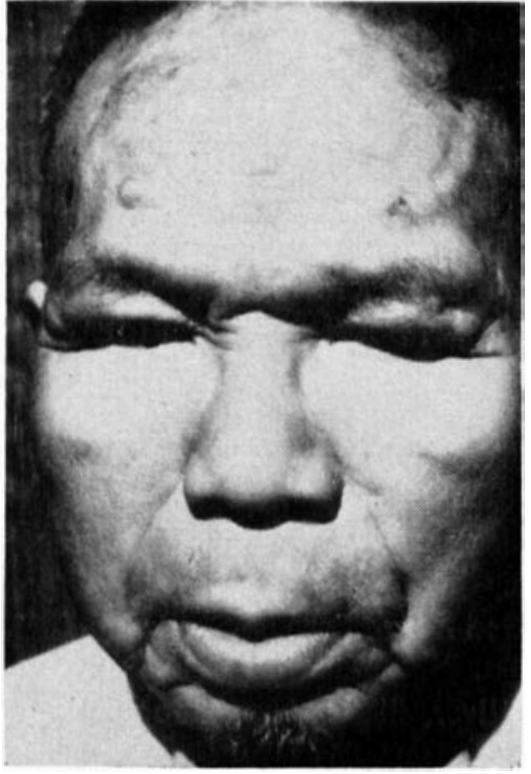

Before Etisul treatment.

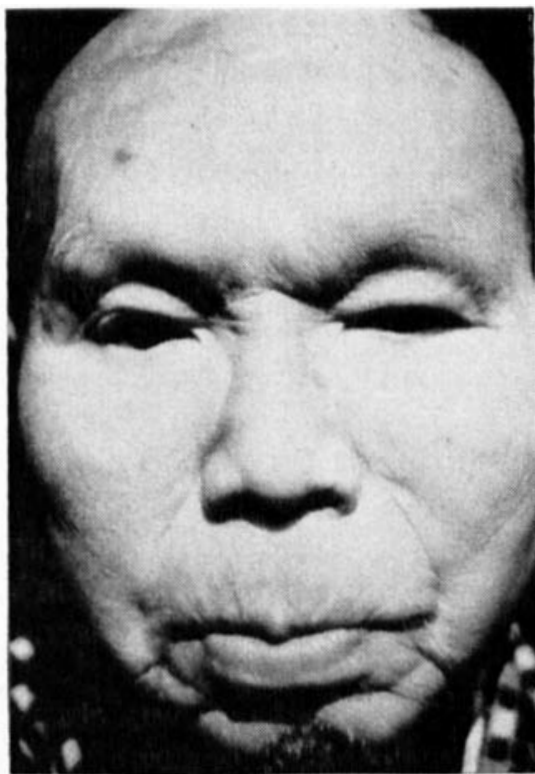

Six months after treatment.

Case 2.

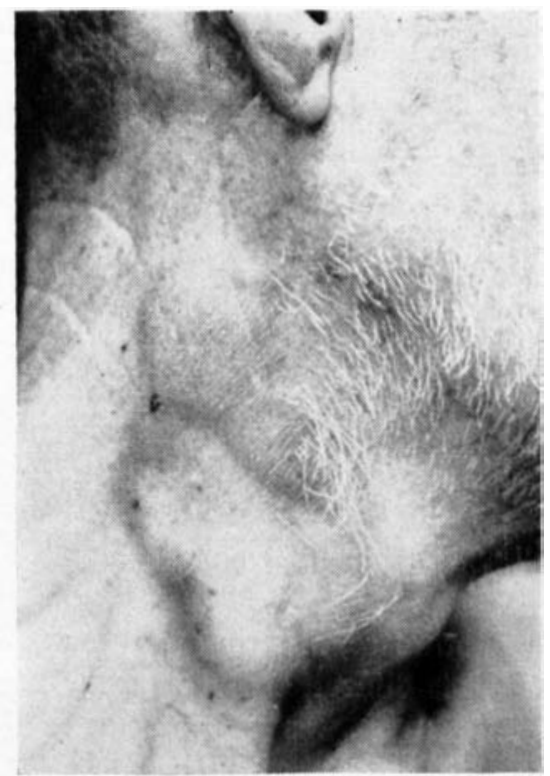

Before Etisul treatment.

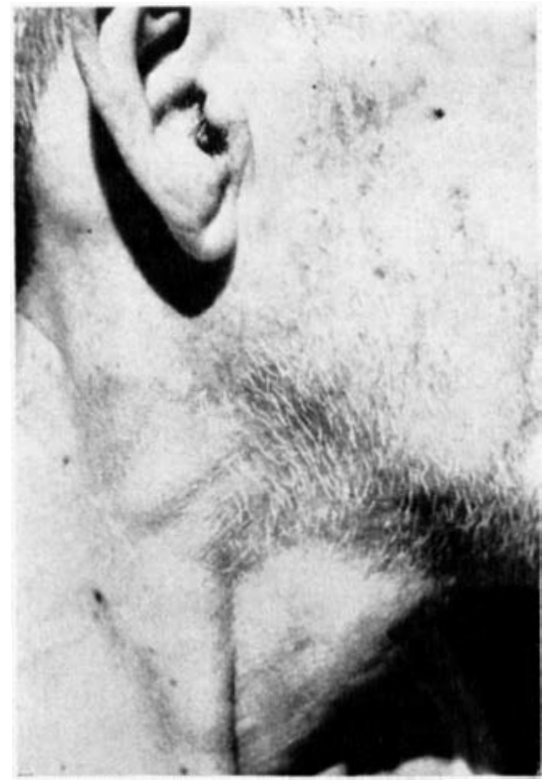

Six months after treatment. 
Case 8

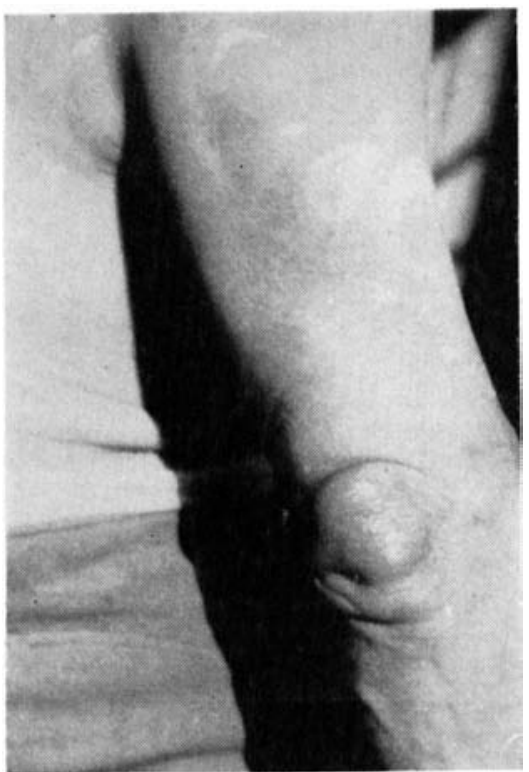

Before Etisul treatment.

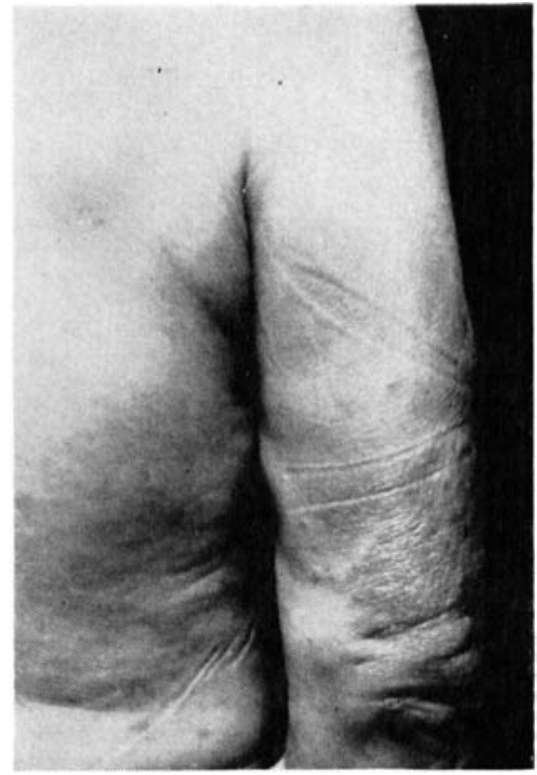

Four months after treatment.

Case 8

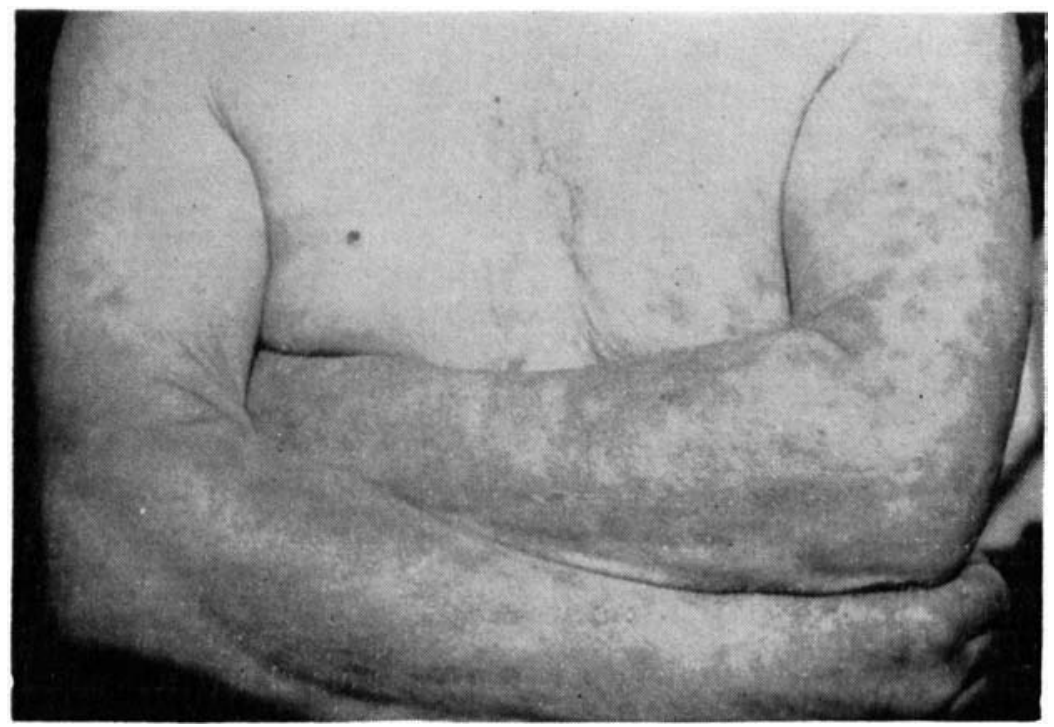

Before Etisul treatment. 
Case 8

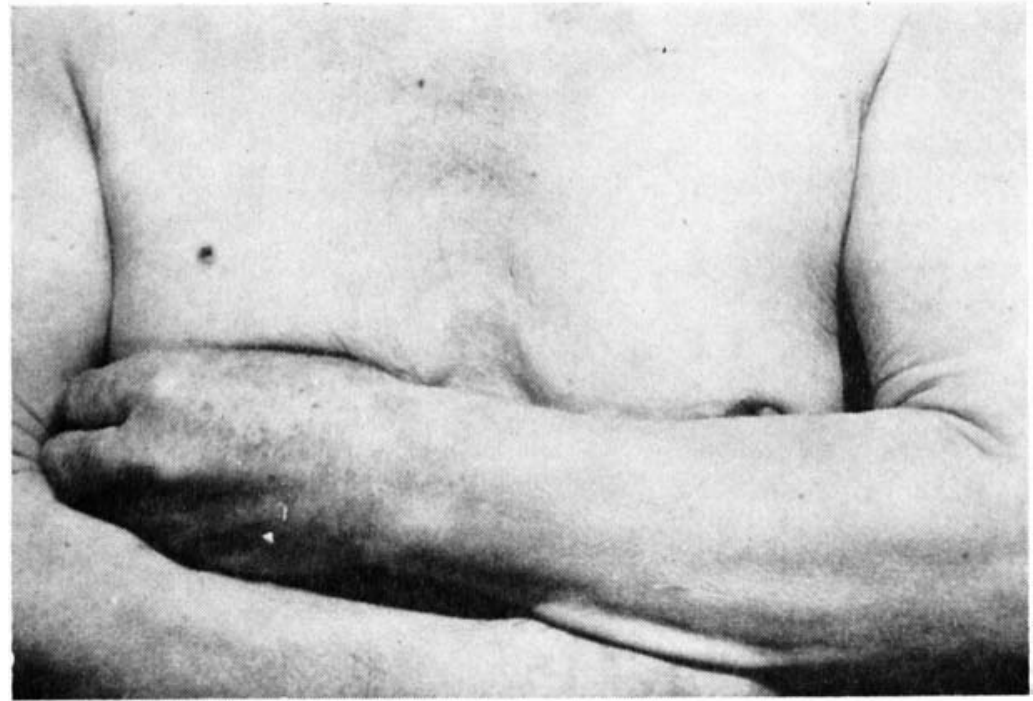

Four months after treatment.

can not be assumed that ETISUL solely effected this decrease, because the bacilli tend to be reduced promptly and spontaneously after the occurrence of this type of reaction.

In the cases of lepromatous leprosy, though the absorption of lesions was clinically and macroscopically observed, and also in some of them the reduction of bacilli was observed, it is difficult to believe that ETISUl excels D.D.S. as DAVEY, et al. or MCGREGor, LECHAT, etc., reported. Our differences in observation may be attributable to the difference in leprosy patients between the southern countries and Japan. In this respect, I wish to wait for further investigation.

In the cases of tuberculoid reactions the drug was well tolerated for relatively long periods, and absorbed satisfactorily, giving good results, while in the cases of lepromatous leprosy the tolerable period was rather short. This was also recognized by DAVEY, et al. In our experience, ETISUL was not effective for more than three months or so. Nevertheless, it should be emphasized that in the treatment of leprosy, as well as other infectious diseases, it is necessary to attack the bacilli in a multiple way through the combined use of more and more different types of drugs, or by using drugs alternately at an appropriate time so that a better therapeutic effect may be achieved. Therefore, if these different types of drugs are clearly recognized to be effective for at least several months, we should use as many as possible, thereby accelerating and enhancing negativization of bacillus. On the other hand, however, the strong and irritating garlic odour of the preparation is a big obstacle to the long treatment 
in leprosaria. Accordingly, we planned to apply this drug first to new patients in a special room. The preparation is recommended to be used not longer than three months, whether it is used alone or combined with other preparations. It should be then replaced thereafter at an appropriate time by other preparations. In spite of the warning, once voiced by MAYER, that drug resistance of bacilli will come to be a problem, as there is some similarity of chemical structure between ETISUL and thiourea derivatives, our experiment could not detect it. This should not give rise to disussion, because we used butoxy-diphenyl-thiourea in Case 1, 3, 4, 8, which were clinically resistant to ETISUL treatment, and observed that both infiltration and swelling subsided again or were more efficiently resolved. However, we have had no experience in using ETISUL in cases resistant to thiourea compounds.

No side effects was observed in the internal organs such as liver, kidney and haematopoietic organs. But it is to be regretted that dermatitis was frequently provoked by this preparation, although it is considered natural since preparations used externally easily cause dermatitis to some extent. It was rather frequent in ETISUL, however. In fact, many patients suffered from generalized dermatitis after a few inunctions, and application could not be continued. Besides this dermatitis, some cases had localized eczema-like patches, which appeared after one or two months treatment and gradually increased in number and size. The occurrence of these eczema-like patches could be due to the fact that we gave the inunctions more frequently (five times a week) than the usual method (two or three times a week).

We also tried ETISUL for the treatment of skin tuberculosis in patients who were not infected with leprosy, but almost all cases were afflicted with dermatitis after a few inunctions. So we could not get any results for tuberculosis.

From these findings, it appeared that leprosy patients were more tolerable to ETISUL than non-leprosy patients. And non-lepromatous patients tend to be more affected by dermatitis than lepromatous patients. Further, concerning the eruptions of the tuberculoid reactions, so-called tuberculoid leprosy (=Non-lepromatous exacerbation) were more easily affected by dermatitis than patients with epithelioid cell reaction in lepromatous leprosy. The dermatitis thus provoked was due to irritation caused by the active ingredient in ETISUL itself rather than the ointment base.

From all these points, it is considered that the dermatitis caused by ETISUL is connected with the degree of ETISUL absorbed from the skin. For lepromatous patients whose sweat glands or superficial vasomotor nerves are diffusely and extensively disturbed, this functional insufficiency may possibly cause poor absorption of the compound. 
TABLE 2 2
Results of Etisul Treatment

\begin{tabular}{|c|c|c|c|c|c|c|c|c|c|c|c|}
\hline \multirow{2}{*}{$\begin{array}{l}\text { Case } \\
\text { No. }\end{array}$} & \multicolumn{3}{|c|}{ Patient's } & \multirow{2}{*}{$\begin{array}{l}\text { Type of } \\
\text { disease }\end{array}$} & \multirow{2}{*}{$\begin{array}{l}\text { Nature of } \\
\text { skin lesion }\end{array}$} & \multirow{2}{*}{$\begin{array}{c}\text { Pre- } \\
\text { treatment }\end{array}$} & \multirow{2}{*}{$\begin{array}{l}\text { Duration } \\
\text { of Etisul } \\
\text { application }\end{array}$} & \multirow[b]{2}{*}{ Clinical observation } & \multirow{2}{*}{$\begin{array}{c}\text { Bacterial } \\
\text { index }\end{array}$} & \multirow{2}{*}{$\begin{array}{l}\text { Side- } \\
\text { effect }\end{array}$} & \multirow[b]{2}{*}{ Result } \\
\hline & Name & $\operatorname{sex}$ & Age & & & & & & & & \\
\hline 1 & T.A. & $\mathbf{M}$ & 65 & $\mathbf{L}$ & new & & 12 months & $\begin{array}{l}\text { In six months leproma diminished by resorption. After } \\
\text { six months thiourea compound was jointly administered. }\end{array}$ & $50-5.0$ & & good \\
\hline 2 & T.O. & $\mathbf{M}$ & 78 & $\mathbf{L}$ & new & & 3 months & $\begin{array}{l}\text { Infiltration gradually resolved, but it appeared again at } \\
\text { the end of the third month. }\end{array}$ & $4.5-4.5$ & & good \\
\hline 3 & I.T. & $\mathbf{M}$ & 60 & $\mathbf{L}$ & Ep. & $\mathbf{P M}$ & 5 months & Infiltration resolved after several months of application. & $3.3 \mathrm{R}-0$ & dermatitis & good \\
\hline 4 & T.M. & $\mathbf{M}$ & 38 & $\mathbf{L}$ & Ep. & $\mathbf{P M}+\mathrm{TCI}$ & 5 months & Infiltration resolved after several months of application. & $5.0 \mathrm{R} .2 .0$ & & good \\
\hline 5 & Y.K. & $\mathbf{M}$ & 55 & $\mathbf{L}$ & reaction & $\mathbf{P M}$ & 5 months & Infiltration gradually resolved. & 1. & & good \\
\hline 6 & M.H. & $\mathbf{M}$ & 65 & $\mathbf{L}$ & reaction & PM & 1 month & Infiltration gradually resolved. & $2.3-2.0$ & dermatitis & fair \\
\hline 7 & A.O. & $\mathbf{M}$ & 32 & $\mathbf{L}$ & E.N.L. & $\mathbf{P M}$ & 2 months & No change. & $5.0-5$ lot & -) dermatitis & unchanged \\
\hline 8 & T.K. & $\mathbf{M}$ & 74 & $\mathbf{L}$ & new & & 4 months & $\begin{array}{l}\text { Combined use with Kanamycin. } \\
\text { leproma was kept flat and infiltration considerably } \\
\text { improved. }\end{array}$ & $5.0-4.0$ & dermatitis & good \\
\hline 9 & B.K. & $\mathbf{M}$ & 59 & $\mathbf{L}$ & new & & 4 months & $\begin{array}{l}\text { Combined use with sulphone compound. } \\
\text { resolved favourably. }\end{array}$ & $5.0-4.0$ & & good \\
\hline 10 & T.N. & $\mathbf{M}$ & 28 & $\mathbf{L}$ & new & & 3 months & In three months diffuse infiltration notably resolved. & $4.3-3.3$ & & good \\
\hline 11 & H.A. & $\mathbf{M}$ & 79 & $\mathrm{~T}$ & new & & 6 months & $\begin{array}{l}\text { In three months entire lesion of infiltration flattened } \\
\text { and resolved. }\end{array}$ & 0. & & good \\
\hline 12 & H.I. & $\mathbf{M}$ & 66 & $T$ & new & & $\frac{1}{2}$ months & $\begin{array}{l}\text { Dermatitis appeared after several applications, and } \\
\text { treatment was discontinued. }\end{array}$ & 0 & dermatitis & - \\
\hline 13 & H.O. & $\mathbf{M}$ & 62 & $T$ & new & & $\frac{1}{2}$ months & $\begin{array}{l}\text { Dermatitis appeared after several applications, and } \\
\text { treatment was discontinued. }\end{array}$ & 0 & dermatitis & - \\
\hline 14 & K.O. & F & 68 & $T$ & new & & $\frac{1}{4}$ months & $\begin{array}{l}\text { Dermatitis appeared after several applications, and } \\
\text { treatment was discontinued. }\end{array}$ & 0 & dermatitis & - \\
\hline 15 & T.I. & $\mathbf{F}$ & 62 & $T$ & new & & $\frac{1}{4}$ months & $\begin{array}{l}\text { Dermatitis appeared after several applications, and } \\
\text { treatment was discontinued. }\end{array}$ & 1.0 & dermatitis & - \\
\hline 16 & S.M. & $\mathbf{F}$ & 30 & $\mathbf{L}$ & new & & 3 months & Leproma diminished and resolved gradually. & $5.0-4.0$ & & good \\
\hline 17 & K.O. & $\mathbf{M}$ & 50 & $\mathbf{L}$ & relapse & $\mathbf{P M}$ & $\frac{1}{4}$ months & Dermatitis appeared, and treatment was discontinued. & 5.0 & dermatitis & - \\
\hline 18 & M. & $\mathbf{M}$ & 39 & $\mathbf{L}$ & Ep. & PM & months & Dermatitis appeared, Md treatment was discontinued. & $5.0 \mathrm{R}$ & dermatitis & - \\
\hline 19 & S.A. & $\mathbf{M}$ & 40 & $\mathbf{L}$ & new & & $\frac{1}{4}$ months & Dermatitis appeared, and treatment was discontinued. & 5.0 & dermatitis & - \\
\hline 20 & I.Y. & $\mathbf{M}$ & 61 & $\mathbf{L}$ & new & & 3 months & Infiltration slightly improved. & 4. & & fair \\
\hline \multirow[t]{2}{*}{21} & N.K. & $\mathbf{F}$ & 55 & $\mathbf{T}$ & new & & $\frac{1}{2}$ months & Dermatitis appeared, and treatment was discontinued. & 0 & dermatitis & 一 \\
\hline & & & & & & & $\begin{array}{l}\text { L: } \\
\text { T: } \\
\text { Ep. } \\
\text { PM: } \\
\text { TCI: }\end{array}$ & $\begin{array}{l}\text { romatous leprosy. } \\
\text { erculoid leprosy. } \\
\text { helioid cell reaction (Pseudo-exacerbation). } \\
\text { min. } \\
\text { oxy-diphenylthiourea. }\end{array}$ & & & $\mathbf{R}$. \\
\hline
\end{tabular}


It was also reported that the white race is more easily affected by dermatitis $(80-90 \%$ ) than the black race (about $50 \%$ ). And Japanese are situated at the middle $(70-80 \%)$. Therefore, the tolerance to ETISUL may somehow differ according to the colour of the skin.

So-called lepra reactions by the employment of ETISUL were not observed. It does not act as strongly as thiourea compounds; the action is very mild and it is absorbed slowly without an intensifying of neuralgia. Therefore, it is suitable for use at the reactional stage, especially at the stage of epithelioid cell reactions. In these cases, it is most appropriate to use this preparation, because the inunction can be performed by the patients themselves, thereby obtaining the motorial exercise of their fingers, thus lessening sequelae and making a good prognosis possible. However, it is a pity that the occurrence rate of dermatitis is higher in tuberculoid cases.

It is desirable to get such a different kind of anti-leprosy drug for external use. We may expect more complete treatment of leprosy by the combined use of different types of preparations, as in tuberculosis.

\title{
Conclusion
}

We used ETISUL, the ointment of a derivative of mercaptan, diethyl-dithiol-isophthalate, for external application and confirmed it to be effective for the treatment of leprosy. It was noted that ETISUL has a mild action and does not provoke lepra reactions, therefore it is suitable for use in cases of tuberculoid lepra reactions.

However, the employment of ETISUL is to be largely restricted because of its tendency to provoke dermatitis. In addition, its effectiveness is of comparatively short duration, not more than several months, and also it has a strong garlic odour.

Nevertheless, it is noteworthy that a new and a different type of anti-leprosy drug has now been added to the line of leprosy treatments. Thus we may approach further to a complete cure of leprosy by a combined use of these drugs.

\author{
Literature \\ Davies, G. E. et al.: Brit. J. Pharm. 11; 351, 1956. \\ NAGUIB, M. et al.: Lancet $1 ; 411,1956$. \\ Solotorovsky, M. et al.: Am. Rev. Tbc. 74; 59, 1956. \\ Davies, G. E. et al.: Brit. J. Pharm. 12; 434, 1957. \\ idem: Nature 182; 664, 1958. \\ Davey, T. F. et al.: Lep. Review 30; 61, 1959. \\ Davey, T. F.: Lep. Review 30; 141, 1959. \\ Ross, C. M. et al.: Lep. Review 31; 260, 1960. \\ LeCHAT, M. F.: Lep. Review 31; 265, 1959. \\ Mukerjee, N. et al.: Lep. Review 31; 275, 1960. \\ McGregor, H.: Lep. Review 32; 36, 1961. \\ Molesworth, B. D.: Lep. Review 32; 150, 1961. \\ MAYER: Lep. Review 30; 25, 1950. \\ Davies, G. E. et al.: Lep. Review $31 ; 52,1960$ \\ Hirako, T.: Jap. Clin. Dermat. \& Urology 16; 247, 1962. \\ HIRAKo, T.: Jap. Clin. of Dermat. 4; 65, 1962.
}

